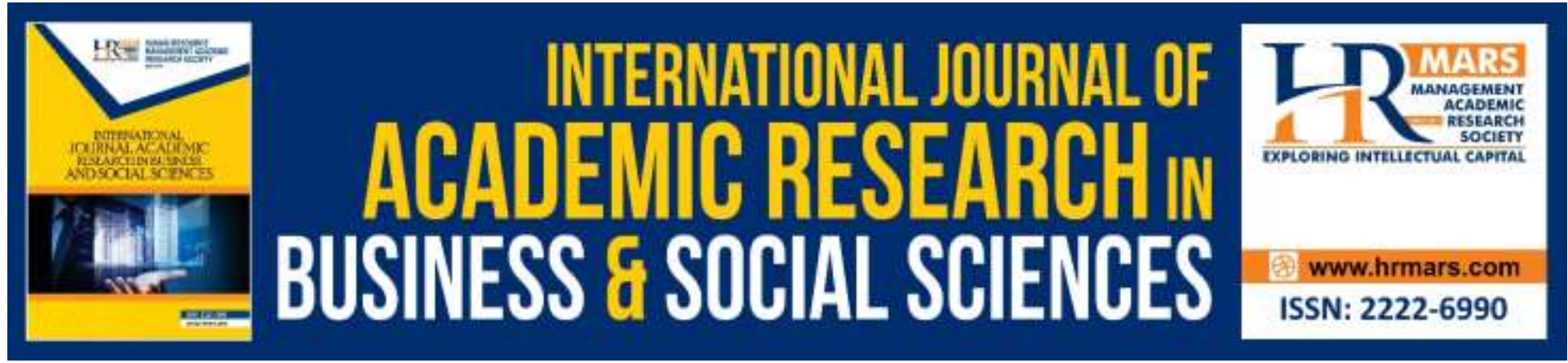

\title{
Factors that Hinder Speaking Arabic as a Third Language
}

Hazrati Yahaya, Janudin Sardi, Mohammad Radzi, Ibrahim Youssef Abdelhamid, Fakulti Pengajian Islam

To Link this Article: http://dx.doi.org/10.6007/IJARBSS/v9-i7/6401

DOI: $10.6007 /$ IJARBSS/v9-i7/6401

Received: 12 May 2019, Revised: 24 June 2019, Accepted: 30 June 2019

Published Online: 23 July 2019

In-Text Citation: (Yahaya, Sardi, Radzi, Abdelhamid, \& Islam, 2019)

To Cite this Article: Yahaya, H., Sardi, J., Radzi, M., Abdelhamid, I. Y., \& Islam, F. P. (2019). Factors that Hinder Speaking Arabic as a Third Language. International Journal of Academic Research in Business and Social Sciences, 9(7), 1346-1354.

\section{Copyright: (C) 2019 The Author(s)}

Published by Human Resource Management Academic Research Society (www.hrmars.com)

This article is published under the Creative Commons Attribution (CC BY 4.0) license. Anyone may reproduce, distribute, translate and create derivative works of this article (for both commercial and non-commercial purposes), subject to full attribution to the original publication and authors. The full terms of this license may be seen at: http://creativecommons.org/licences/by/4.0/legalcode

\section{Vol. 9, No. 7, 2019, Pg. 1346 - 1354}

Full Terms \& Conditions of access and use can be found at http://hrmars.com/index.php/pages/detail/publication-ethics 


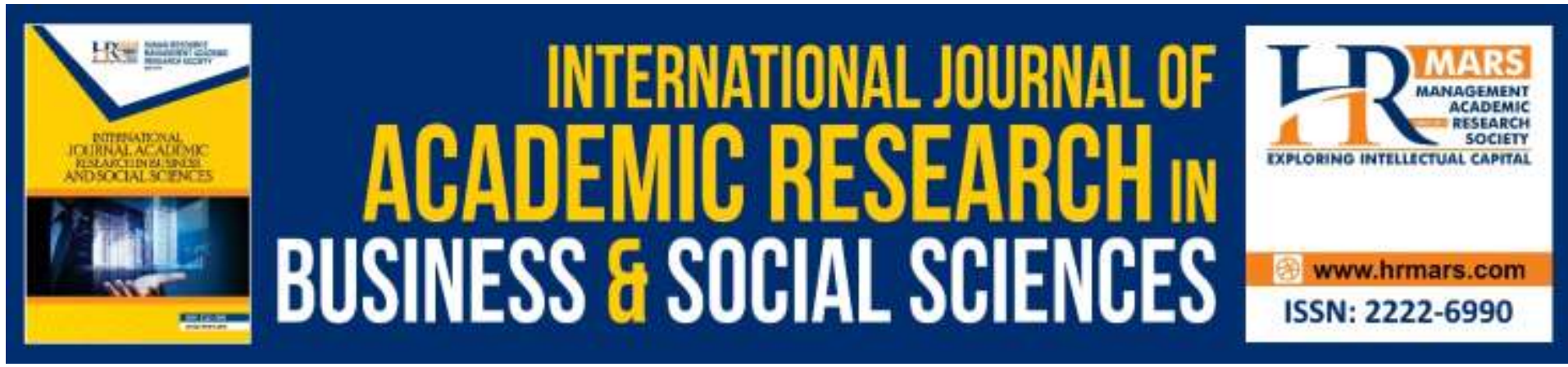

\title{
Factors that Hinder Speaking Arabic as a Third Language
}

\author{
Hazrati Yahaya, Janudin Sardi, Mohammad Radzi, Ibrahim \\ Youssef Abdelhamid \\ Akademi Pengajian Bahasa, Universiti Teknologi MARA (UiTM) \\ Shah Alam, Selangor, Malaysia
}

\section{Fakulti Pengajian Islam}

Universiti Kebangsaan Malaysia (UKM), Bangi, Selangor, Malaysia

Email:hazratiy@gmail.com

\begin{abstract}
Learning Arabic in Malaysia has started a long time ago. However, studies have shown that the level of language skills among students is still unsatisfactory. For speaking skill, students are facing difficulties to speak Arabic well, because language errors have always been the case. Due to this reason, it is necessary for a study to be conducted with the purpose of identifying the constraints that are stopping them from speaking Arabic properly as well as the implications of this problem. To identify the constraint factors, a total of 98 students who attended the first level Arabic course at UiTM Shah Alam were chosen as respondents. A survey form was used as a research instrument. The data were analysed based on the basic descriptive to find frequency, percentage and mean in distribution. The findings show that the most important constraints are the lack of vocabulary and the environment, that do not encourage them to converse in Arabic, leading to the inability to speak the language fluently. This study also proposed three ways to overcome this problem, namely using an Arabic language learning strategy, implementing well-designed teaching methods for speaking skills and the need to increase reading materials.
\end{abstract}

Keywords: Learning Arabic Language, Language Skills, Speaking Skill, Third Language, Hindrance Factors

\section{Introduction}

In the 70s, the teaching of Arabic language was given attention by the Ministry of Education of Malaysia (MOE) by applying Arabic students into the teaching syllabus. It is now being offered at religious national high schools throughout the country. The teaching of Arabic language focuses on speaking skills to enable students to speak Arabic. The curriculum was formulated specifically to achieve the target and the textbooks were written by Arabic experts. The Arabic language is offered to students from Form One to Form Five. The development of Arabic language teaching has been further stimulated by offering the Arabic 
language students in full boarding schools and daily schools. In that development, the measure is divided into two parts. Upper Level Arabic is a syllabus designed for national religious high schools specifically for Form Four and Form Five students, while Communicative Arabic is the metric for other schools. Similarly, the development of Arabic language teaching across the school boundaries is offered in higher education centres as an optional language course.

The offering of Arabic as a foreign language subject in Malaysia is becoming increasingly widespread as an elective language as well as a programme at the university level for obtaining a specialisation degree in its field. Universiti Teknologi MARA (UiTM) has made Arabic as one of the university's requirement courses, in line with other foreign languages. Bachelor students in UiTM are required to choose one of the three languages offered and learn it for three semesters. This course is designed for two credit hours that equals two consecutive hours a week in each semester. During the three semesters, students take the third language class as much as six credit hours equivalent to 84 hours of meetings, which is 28 hours of meetings per semester (The Academic Affairs Division, 2009). Therefore, this study will focus on the aspect of identifying constraints in the Arabic language spoken by students who take Arabic language course as a third language, thus providing suggestions on solving the problem so that they are able to speak well in Arabic.

\section{Problem Statement}

Arabic is the national language for Arab people and is a language of politics, beliefs, business, thought and culture to Muslims or ratio to 1 out of 5 world's population today including Malaysia (Zainur \& Rosni, 2007). Arabic speakers today have been estimated to exceed 422 million worldwide (Ku Fatahiyah et al., 2014). Besides, Arabic is also developing as a world language in the global education flows. The establishment of units and institutions of study in countries other than Arab countries, such as America, Britain, including Malaysia proves the acceptance of this language internationally (Wan, 2006). Malaysia has also taken a step forward to introduce Arabic language students at all levels of education including the higher education levels. Arabic has been one of the elective courses in the university as well as a compulsory course in several faculties. However, this effort is seen to be unuseful when the mastery of the students in this language is weak (Al-Muslim \& Zamri, 2012).

Generally, there are four essential skills in language teaching, i.e.listening, speaking, reading and writing skills. Therefore, the teaching of Arabic in Malaysia has placed the goal of enabling students to master the four language skills (Ismail et al., 2011). Effective domination in Arabic should be applied through speaking. However, according to the recent studies, the level of language skills among students is still unsatisfactory (Azlan \& Rosni, 2015). This situation can be seen through Ghazali (2012) on UiTM students showing that students' achievement in speaking skills is not encouraging because they have been rated at levels $A 1$ and A2 on the Common European Framework of Reference for Languages (CEFR) scale. This situation is also supported by the findings of Sahabudin (2003) related to the achievement of Arabic language proficiency of speaking skill that involved 100 UiTM Arabic language students as respondents of the study. He found that the achievement of students in the mastery of the Arabic language is poor and unsatisfactory. Not only does this situation happen to students in UiTM it also happens to students in other institutes of higher learning. The evidence can be seen in previous studies (Norhayati et al., 2013). 
Reflecting on the weaknesses in mastering the Arabic speaking skills above, this study attempts to uncover the students'problem on the situation that occurred to identify their constraints when speaking Arabic. This issue is explained through the following two questions: 1) What are the types of constraints that occur in Arabic language speaking?; and 2) What are the implications of the problems?

\section{Study Objectives}

The objectives of this study are to:

1- Identify the constraint factors faced by students in Arabic speaking skills.

2- Identify solutions to address these problems.

\section{Methodology}

Questionnaire was used in this study to identify the constraint factors faced by students speaking in Arabic language. The sample was selected using a simple random sampling involving 98 students who attended the first level Arabic course at UiTM Shah Alam. The process of data analysis was done using software SPSS (Statistical Package for the Social Sciences) Version 22 to answer the first objective of the study. The questionnaire was modified from Adnan (2014), which used a five-point Likert scale: 1 = strongly disagree, 2 = disagree, $3=$ Less agree, $4=$ Agree and $5=$ strongly agree. The respondents were asked to mark one of the numbers to indicate their consent to statements related to constraints in Arabic language. The questionnaire consisted of two parts:

Part A: (Demographic information). This section contained two statements for information about respondents' background i.e. gender and status of learning Arabic language.

Part B: The constraints in Arabic speaking.

The data obtained were analyzed through descriptive statistics as they would be able to provide information directly and easily. Descriptive statistics used were frequency, percentage, mean and standard deviation. The mean value obtained in this study was interpreted by means of interpretation of descriptive statistical findings proposed by Nunnally and Bernstein (1994) as shown in Table 1 below. To interpret the mean score, the mean value of 1.00 to 2.00 is low; the mean value of 2.01 to 3.00 is at low moderate level; the mean value of 3.01 to 4.00 is at moderate high level and the high level min value is 4.01 to 5.00 .

Table 1. Score Min Interpretation Scale (Nunnally \& Bernstein, 1994)

\begin{tabular}{ll}
\hline Duration/Min & Interpretation \\
\hline $1.00-2.00$ & Low \\
$2.01-3.00$ & Medium Low \\
$3.01-4.00$ & Medium high \\
$4.01-5.00$ & High \\
\hline
\end{tabular}

\section{Result and Discussion} Respondent Profile

A sample of 95 respondents, which comprised of 26 male students and 69 female students was chosen in this study. A total of 79 students have studied Arabic and 16 students that have never studied Arabic. 
Gender

\begin{tabular}{lll}
\hline & Number & Percentage \\
\hline Male & 26 & 27.4 \\
Female & 69 & 72.6 \\
\hline
\end{tabular}

Have learned Arabic before

\begin{tabular}{lll}
\hline & Number & Percentage \\
\hline Yes & 79 & 83.2 \\
No & 16 & 16.8 \\
\hline
\end{tabular}

Table 2 : Factors in lack of using Arabic language

\begin{tabular}{|c|c|c|c|c|c|c|c|c|}
\hline No. & Statement & STS & TS & TP & $S$ & SS & Min & Stages \\
\hline K1 & $\begin{array}{l}\text { I'm shy to } \\
\text { speak } \\
\text { in Arabic } \\
\text { language }\end{array}$ & $\begin{array}{l}16 \\
(16.8 \%)\end{array}$ & $\begin{array}{l}35 \\
(36.8 \%)\end{array}$ & $\begin{array}{l}21 \\
(22.1 \%)\end{array}$ & $\begin{array}{l}18 \\
(18.9 \%)\end{array}$ & $\begin{array}{l}5 \\
(5.3 \%)\end{array}$ & 2.59 & Medium low \\
\hline K2 & $\begin{array}{l}\text { I feel unsure } \\
\text { when } \\
\text { speaking in } \\
\text { Arabic }\end{array}$ & $\begin{array}{l}6 \\
(6.3 \%)\end{array}$ & $\begin{array}{l}30 \\
(31.6 \%)\end{array}$ & $\begin{array}{l}15 \\
(15.8 \%)\end{array}$ & $\begin{array}{l}41 \\
(43.2 \%)\end{array}$ & $\begin{array}{l}3 \\
(3.2 \%)\end{array}$ & 3.05 & $\begin{array}{l}\text { Medium } \\
\text { high }\end{array}$ \\
\hline K3 & $\begin{array}{l}\text { I do not have } \\
\text { much Arabic } \\
\text { vocabulary }\end{array}$ & $\begin{array}{l}0 \\
(0.0 \%)\end{array}$ & $\begin{array}{l}10 \\
(10.5 \%)\end{array}$ & $\begin{array}{l}18 \\
(18.9 \%)\end{array}$ & $\begin{array}{l}49 \\
(51.6 \%)\end{array}$ & $\begin{array}{l}18 \\
(18.9 \%)\end{array}$ & 3.79 & $\begin{array}{l}\text { Medium } \\
\text { high }\end{array}$ \\
\hline K4 & $\begin{array}{l}\text { I do not } \\
\text { master the } \\
\text { language } \\
\text { structure well } \\
\text { I cannot }\end{array}$ & $\begin{array}{l}2 \\
(2.1 \%)\end{array}$ & $\begin{array}{l}13 \\
(13.7 \%)\end{array}$ & $\begin{array}{l}39 \\
(41.1 \%)\end{array}$ & $\begin{array}{l}33 \\
(34.7 \%)\end{array}$ & $\begin{array}{l}8 \\
(8.4 \%)\end{array}$ & 3.34 & $\begin{array}{l}\text { Medium } \\
\text { high }\end{array}$ \\
\hline K5 & $\begin{array}{l}\text { pronounce } \\
\text { the letters } \\
\text { correctly }\end{array}$ & $\begin{array}{l}11 \\
(11.6 \%)\end{array}$ & $\begin{array}{l}45 \\
(47.4 \%)\end{array}$ & $\begin{array}{l}21 \\
(22.1 \%)\end{array}$ & $\begin{array}{l}13 \\
(13.7 \%)\end{array}$ & $\begin{array}{l}5 \\
(5.3 \%)\end{array}$ & 2.54 & Medium low \\
\hline K6 & $\begin{array}{l}\text { I feel afraid to } \\
\text { speak Arabic }\end{array}$ & $\begin{array}{l}9 \\
(9.5 \%)\end{array}$ & $\begin{array}{l}35 \\
(36.8 \%)\end{array}$ & $\begin{array}{l}31 \\
(32.6 \%)\end{array}$ & $\begin{array}{l}17 \\
(17.9 \%)\end{array}$ & $\begin{array}{l}3 \\
(3.2 \%)\end{array}$ & 2.68 & Medium low \\
\hline K7 & $\begin{array}{l}\text { The } \\
\text { environment } \\
\text { does not } \\
\text { encourage me } \\
\text { to speak } \\
\text { Arabic } \\
\text { language }\end{array}$ & $\begin{array}{l}5 \\
(5.3 \%)\end{array}$ & $\begin{array}{l}14 \\
(14.7 \%)\end{array}$ & $\begin{array}{l}13 \\
(13.7 \%)\end{array}$ & $\begin{array}{l}45 \\
(47.4 \%)\end{array}$ & $\begin{array}{l}18 \\
(18.9 \%)\end{array}$ & 3.60 & $\begin{array}{l}\text { Medium } \\
\text { high }\end{array}$ \\
\hline & Overall & & & & & & 3.08 & $\begin{array}{l}\text { Medium } \\
\text { high }\end{array}$ \\
\hline
\end{tabular}

Table 2 shows the findings obtained based on the students' assessment of the constraint factors in the Arabic language. The findings found that the sample agreed on the lack of vocabulary as the main constraint in speaking the language. This can be seen clearly at min for this limiting factor of 3.79. This findings also coincide with some previous studies, 
which found that the students did not have many vocabularies (Adnan \& Muhammad, 2014). The effect from this situation will cause the message that is conveyed by students unclear (Gan, 2012). The study sample also conceded that the second highest constraint factor was that the environment did not encourage students to speak Arabic, which reached a min of 3.60. This is because most people around them speak more in native language and second language, which is English. Therefore, the circumstances around them do not encourage them to speak Arabic.

The third most constraining factor is that they are not mastering the language well. That situation was also proven through the study by Azani (2012) which were faced by the students when they speak Arabic through their involvement in speaking activities i.e. acting. The fourth highest constraint factor is lack of self confidence to speak Arabic, shown at min of 3.05. Due to having lack of self confidence to speak Arabic, students become less initiative to diversify the appropriate speaking strategies to address the problems they facewhile speaking up to some of the students who prefer to use the mother tongue in place of the third language or they only keep silent (Alibakhshi \& Padiz, 2011).On the other hand, other constraints factors have a mean less than 3.0, which are being ashamed when speaking in Arabic, having fear to speak the language, as well as the inability to pronounce the words correctly.

\section{Implications}

The findings of the study have shown the constraints and factors faced by students in the spoken Arabic language. From the findings, there are three major implications that can be summarised. It is related to students strategies in the effort of learning Arabic skills, and learning methods that need to be addressed, especially in speaking skills and reference materials that provide language especially speaking skills to students.

\section{Implications on Learning Strategy}

From a strategy perspective, students should have their own strategies for learning especially speaking skills. Zamri et al. (2010) had listed 15 items relating to mastering speaking skills while learning Malay and English in the classroom. Speaking strategies in classroom include giving full attention when teacher speaks, paying close attention when a friend speaks, speaking without mixing with a dialect/foreign language, and being brave to speak during language learning. In Mastura \& Kaseh (2012) and Rosni et al. (2013), they indicated that students studying the Arabic language are less likely to use the learning strategy and unaware of the use learning strategy.

\section{Implications on Teaching Methods}

Based on the findings of the students' assessment of the constraint factors in speaking Arabic language, the main constraint in Arabic language is the lack of vocabulary. To enhance vocabulary learning, concentration should be emphasised on reading skills. This is to enable students to master their speaking skills and to develop sentences with new words. Hanan (2011) suggested that vocabulary mastery activities should be conducted through reading and hearing. As for Nurul (2014), students should be encouraged to read newspapers and even Arabic magazines to enhance the mastery of vocabulary. In addition, students are encouraged to watch films, dramas and also listen to songs using the medium of Arabic to assist in the mastery of Arabic vocabulary. According to Izzah (2014), educators must run a variety of 
language game activities to supplement student vocabulary. Similarly, Nurain (2014) suggested that language activity should be intensified to add and increase vocabulary.

\section{Implications on Reference Materials}

From the point of reference implications, educators should provide appropriate materials to assist students in improving and increasing their vocabulary. Based on the findings of the study of Noor (2018), educators still lack the use of referral resources in teaching and learning Arabic in the classroom. Almost some of them have no references or source for sufficient Arabic teaching. The findings also show that teachers only rely entirely on the use of textbooks during the Arabic language teaching session. Using less references also implies the occurrence of weakness in speaking skills. According to Kamarulzaman (2011), external factors, such as Arabic language teaching materials contribute mostly to good language skills. It is important to establish the aspect of speech.

\section{Conclusion}

The results of this study clearly show the constraints in Arabic speaking skills. The main factor in supreme constraints in Arabic speaking skills is the lack of vocabulary. The second highest factor is that the environment does not encourage students to speak in Arabic. On the other hand, the third factor is that there is no mastery of the language. To overcome these problems, the learning and teaching process for Arabic language proficiency in subjects should be increased and multiplied, not only limited to conventional methods. This is because students in the recent globalisation era are more likely to learn from modern and technologyfriendly alternatives and the Internet. These alternatives are not just interesting but also can be used as an interactive and beneficial reference materials as well (Rosni, 2007). It is in line with the study of Ainol and Isarji (2009) in creating a conducive learning environment by not only using lecture rooms, but also to expose them to an external environment that can further enhance the mastery of their speaking skills more effectively.

\section{References}

Adnan., \& Firdaus, M. A. M. (2014). Kekangan bertutur dalam bahasa arab di kalangan pelajar BASL, Proceedings of International Research Management and Innovation Conference, (pp.584-599).

Mardziah, A. Z. \& Isarji, S. (2009). Motivation to learn a foreign language in Malaysia. GEMA

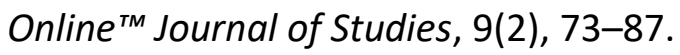

Alibakhshi, G., \& D. Padiz, (2011). The Effect of Teaching Strategic Competence on speaking Performance of EFL Learners. Journal of Language Teaching and Research. 2(4), 941947

Al-Muslim, M. \& Zamri, A. (2012). Pengajaran dan pembelajaran bahasa Arab: satu tinjauan literatur di Negeri Sembilan. Prosiding Persidangan Kebangsaan Pengajaran Dan Pembelajaran Bahasa, (pp.15-33).

Azani, I. @ Y., Azman, C. M. \& Mat, T. P. (2012). Membina kemahiran pertuturan menerusi aktiviti lakonan dalam pengajaran bahasa Arab. GEMA OnlineTM Journal of Language Studies, 12(1), 325-337.

Azlan, S. \& Rosni, S. (2015). Persepsi pelajar universiti awam terhadap kesalahan bahasa Arab, faktor penyumbang dan implikasi. Sains Humanika. 6(1), 35-42. 
Gan, Z. (2012). Understanding L2 speaking problems: Implications for ESL Curriculum Development in a Teacher Training Institution in Hong Kong. Australian Journal of Teacher Education. 37(1), 42-59.

Ghazali, Y. (2012). Penilaian kemahiran lisan dalam kurikulum bahasa arab di Universiti Teknologi Mara (UiTM). Tesis Ph.D. Bangi: Universiti Kebangsaan Malaysia.

Siniy, H. H. (2014). Marifah mufradat fil maqalah islamiah lada tholabah sanah rabiah fi kullia syariah wal qanun biljamiah. Projek Ilmiah Fakulti Pengajian Bahasa Utama. Nilai : Universiti Sains Islam Malaysia.

Izzah, F. B. (2014). Faalaiat thariqah lu'bah lughawiah fi taalum lughah arabiah lada tholabah sanah thaniah fil madrasah thanawiah Pekan Baru Muar Johor. Projek Ilmiah Fakulti Pengajian Bahasa Utama. Nilai : Universiti Sains Islam Malaysia.

Kamarulzaman, A. G. (2011). Kebolehbacaan buku teks bahasa arab tinggi berasaskan ujian

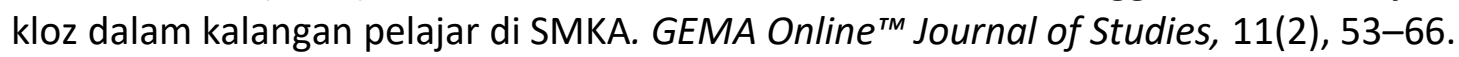

Fatahiyah, K. A., Awatif, A. R., \& Hairun Najuwah, J. (2014). Tahap kemahiran asas bahasa Arab di IPT Malaysia. GSE E-Journal of Education,1(2), 2289-6880.

Mainizar, N. (2011). Korelasi motivasi belajar Bahasa Arab dengan minat berkomunikasi dalam Bahasa Arab pada mahasiswa jurusan pendidikan Bahasa Arab Fakultas Tarbiyah dan Keguruan Universitas Islam Negeri Sultan Syarif Kasim Riau. Jurnal Sosial Budaya, 8(1), 97-113.

Arshad M. \& Bakar, K. A. (2012). Penggunaan strategi pembelajaran kemahiran bertutur bahasa arab: kajian di Pusat Asasi Uiam. Prosiding Persidangan Kebangsaan Pengajaran Dan Pembelajaran Bahasa, (pp.139-155).

Nadwah, D. \& Nadhilah, A. P. (2014). Permasalahan pertuturan dalam Bahasa Arab sebagai bahasa kedua. GEMA Online ${ }^{T M}$ Journal of Studies, 14(1), 117- 133.

Shamshinar, N. Z., Norul, N. A., Hafizi, M. S. F., Izzuddin, M. P. \& Haslina, H. (2018). Penggunaan sumber rujukan dalam pengajaran bahasa arab: satu tinjauan dari perspektif guru bukan opsyen. The Online Journal of Islamic Education, 6(2), 9-17.

Ain, N. R. (2014). Anshithah addaurah almukathafah bimaharat lughatil quran fi raf'i mustawal maharat allughawiyah lada tholabah sanah ula bilkulliyah. Projek Ilmiah Fakulti Pengajian Bahasa Utama. Nilai: Universiti Sains Islam Malaysia.

Norhayati, C. H., Shaferul, H. S., \& Fauzi, M. A. H. (2013). Persepsi pelajar terhadap penggunaan animasi dalam pembelajaran bahasa Arab. Jurnal Teknologi, 63(1), 25-29.

Afiah, N. A. S. (2014). Iktisab almufradat ashahiah fil jaridah arabiah lada tullab assanah rabiah fi kuliyyah alluughah al arabiah fil kuliah. Projek Ilmiah Fakulti Pengajian Bahasa Utama. Nilai: Universiti Sains Islam Malaysia.

Rosni, S., Fauzi, M. A. H., Shaferul, H. S. \& Amizan, H. M. (2013). Aktiviti pengajaran kemahiran

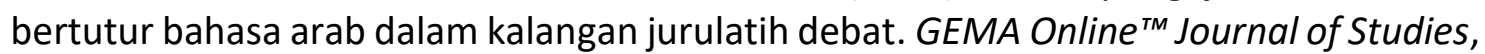
13(2), 99-116.

Rosni, S. (2007). Penggunaan internet dalam pengajaran bahasa: kajian terhadap bahasa Arab komunikasi pelancongan. Malaysian Education Dean's Council Journal, 1(2), 83-95.

Sahabudin, S. (2003). Masalah penguasaan bahasa Arab komunikasi di kalangan pelajar Melayu: Satu kajian kes. Tesis Sarjana, Fakulti Bahasa dan Linguistik, Universiti Malaya.

Sueraya C. H., Ismail, S. A., Arifin, M. \& Ismaiel, H. A. M. (2010). Understanding ArabicSpeaking Skill Learning Strategies among Selected Malay Learners: A Case-Study At The International Islamic University Malaysia (IIUM), Contemporary Issues in Education Research. ProQuest Education Journals, 3(8), 9-20. 
Azura, W. A., Lubna, A. R., Arnida A. B. \& Ahmad P. N. (2007). Pendekatan dan strategi efektif dalam penguasaan bahasa Arab. Bandar Baru Nilai: Penerbit Universiti Sains Islam Malaysia.

Rijal, Z. A. R. \& Rosni, S. (2007). Kesan bahasa Arab dalam peradaban melayu di Malaysia. Penerbit KUIM, Negeri Sembilan.

Zamri, M., Amin, M. E. \& Rahimi, N. M. Y. (2010). Strategi Pembelajaran Bahasa Melayu dan Inggeris Pelajar Cemerlang. Fakulti Pendidikan, Universiti Kebangsaan Malaysia.

Zawawi, I., Halim, A. T., Rahimi, N. M. Y. \& Ala-Uddin, M. O. (2011). Teknik Pengajaran kemahiran Bertutur Bahasa Arab di SMKA di Malaysia. GEMA Online Journal of Language Studies 11(2), 67-82. 